\title{
EFEKTIFITAS PENGENDALIAN INTERNAL, BUDAYA ETIS ORGANISASI DAN KETAATAN ATURAN AKUNTANSI TERHADAP KECENDERUNGAN KECURANGAN AKUNTANSI
}

\author{
Zainuddin \\ Fakultas Ekonomi Universitas Khairun Ternate \\ Jalan Pertamina Kelurahan Gambesi Kota Ternate \\ Email:jhay21.zainuddin@gmail.com
}

Abstract

This study was aimed at discovering the perception of the financial workers in SKPDs in Ternate city about the effect of effectiveness in internal control, the organization's ethic culture and compliance to accounting rules on the tendency of accounting fraud. This study was conducted with SKPDs of the Ternate cities Government, as one of the implementing lamenting of the region's government in the form of offices. The sample consisted of 72 workers in the offices of the Ternate cities government. The data collection was done by distributing questionnaires with a set of questions or statements to the respondents to be answered using Likert scale. The data analysis techniques used were validity and reliability testing, normality testing, Mullticolinearity testing, Heteroscedasticity testing and hypothesis testing using SPSS program 21.0 for Windows. The results showed that: (1) there was a negative and significant effect between the effectiveness in internal control and the tendency of accounting fraud in the SKPDs in Ternate city, (2) there was a negative and significant effect between the organization's ethic culture and the tendency of accounting fraud in the SKPDs in Ternate city, (3) there was a negative and significant effect between the compliance to accounting rules and the tendency of accounting fraud in the SKPDs in Ternate city.

Keywords: Organization's ethic culture, effectiveness in internal control, compliance to accounting rules and tendency of accounting fraud. 
Abstrak

Penelitian ini bertujuan untuk menggali persepsi para pegawai pengelola keuangan pada Satuan Kerja Perangkat Daerah (SKPD) Kota Ternate mengenai pengaruh efektifitas pengendalian internal, budaya etis organisasi dan ketaatan aturan akuntansi terhadap kecenderungan kecurangan akuntansi. Penelitian ini dilakukan pada SKPD Pemerintah Kota Ternate yaitu salah satu unsur pelaksanaan pemerintah daerah yang berupa dinas-dinas. Sampel penelitian ini sejumlah 72 pegawai pada dinas-dinas Pemerintah Kota Ternate. Pengumpulan data dilakukan dengan cara penyebaran kuesioner dengan memberi seperangkat pertanyaan atau pernyataan tertulis kepada responden untuk dijawabnya dengan menggunakan skala likert. Teknik analisis data yang digunakan yaitu uji validitas dan reliabilitas, uji normalitas, uji multikolinearitas, uji heteroskedastisitas, dan uji hipotesis menggunakan analisis regresi linear berganda (Multiple Regression Analysis) dengan menggunakan program SPSS 21.0 for Windows. Hasil penelitian ini menunjukkan bahwa: (1) terdapat pengaruh negatif dan signifikan antara efektifitas pengendalian internal terhadap kecenderungan kecurangan akuntansi pada Satuan Kerja Perangkat Daerah (SKPD) Kota Ternate, (2) terdapat pengaruh negatif dan signifikan antara budaya etis organisasi terhadap kecenderungan kecurangan akuntansi pada Satuan Kerja Perangkat Daerah (SKPD) Kota Ternate, (3) terdapat pengaruh negatif dan signifikan ketaatan aturan akuntansi terhadap kecenderungan kecurangan akuntansi pada Satuan Kerja Perangkat Daerah (SKPD) Kota Ternate.

Kata kunci: budaya etis organisasi, efektifitas pengendalian internal, ketaatan aturan akuntansi dan kecenderungan kecurangan akuntansi

\section{PENDAHULUAN}

Fenomena yang terjadi dalam perkembangan sektor publik di Indonesia dewasa ini adalah menguatnya tuntutan akuntabilitas atas lembaga-lembaga publik, baik di pusat maupun daerah. Akuntabilitas dapat diartikan sebagai bentuk kewajiban mempertanggungjawabkan keberhasilan atau kegagalan pelaksanaan misi organisasi dalam mencapai tujuan dan sasaran yang telah ditetapkan sebelumnya, melalui suatu media pertanggungjawaban yang dilaksanakan secara periodik (Mardiasmo, 2006). Instansi pemerintahan merupakan suatu organisasi yang mempunyai berbagai ragam tujuan. Aktivitas dalam instansi pemerintah selalu di arahkan untuk mencapai tujuan yang telah ditetapkan sebelumnya.Manusia sebagai penghuni sebuah organisasi bisa terbentuk oleh budaya organisasi, bahkan bisa merubah budaya organisasi yang sebelumnya.Budaya yang kuat dalam organisasi dapat memberikan paksaan atau dorongan kepada para anggotanya untuk bertindak atau berperilaku sesuai dengan yang diharapkan oleh organisasi (Jusanto, dkk., 2014). 
Peran etika dalam sebuah organisasi sangatlah penting, etika yang baik harus dikembangkan dan dijadikan panutan untuk mencapai kerja yang baik pula. Organisasi tidak mungkin berfungsi secara bertanggungjawab tanpa memiliki etika ketika menjalankan urusan kesehariannya. Setiap organisasi, baik publik maupun swasta sepatutnya memiliki dan menerapkan suatu tatanan perilaku yang dihormati oleh setiap aggotanya dalam mengelola kegiatan operasi. Dengan mematuhi aturan dan kebijakan yang ada dalam organisasi tersebut diharapkan dapat mengoptimalkan kinerja dan produktivitas para karyawan untuk mencapai tujuan (Atom, 2012).

Laporan keuangan merupakan akhir dari proses akuntansi yang dirancang untuk memberikan informasi kepada calon investor, calon kreditor, pengguna laporan untuk pengambilan keputusan bisnis. Bagi pihak manajemen, laporan keuangan dapat dijadikan sebagai bahan pertimbangan dalam menetapkan rencana kegiatan perusahaan untuk periode yang akan datang. Selain itu, laporan keuangan juga bermanfaat bagi manajemen untuk pelaksanaan kegiatan operasi sehari-hari. Informasi yang terdapat dalam laporan keuangan memberi dasar bagi manajemen untuk membuat perencanaan. Dengan demikian, informasi yang tersedia dalam laporan keuangan sangat penting bagi investor dan manajemen sehingga harus dapat diandalkan. Mengingat pentingnya laporan keuangan suatu perusahaan, maka laporan keuangan harus disusun sebaik mungkin sesuai dengan data yang akurat sesuai dengan aturan akuntansi yang berlaku. Menurut PSAK No.1 tentang Penyajian Laporan Keuangan revisi tahun 2009 Paragraf ke 24 menyebutkan tentang karakteristik kualitatif laporan keuangan yang merupakan ciri khas yang membuat informasi dalam laporan keuangan berguna bagi pemakai, yaitu: dapat dipahami, relevan, keandalan, dan dapat diperbandingkan. Namun pada kenyataannya masih terjadi tindakan penyimpangan pada laporan keuangan sehingga informasi yang ada dalam laporan keuangan menjadi tidak relevan dan tidak dapat diandalkan. Tindakan penyimpangan dalam laporan keuangan ini merupakan salah satu tindakan kecurangan akuntansi, berupa penghilangan jumlah atau pengungkapan dalam laporan keuangan untuk mengelabuhi pemakai laporan keuangan.Tindakan yang sering dilakukan dalam praktik kecurangan akuntansi adalah tindakan yang menyebabkan kesalahan pelaporan dalam laporan keuangan, atau suatu tindak kesengajaan untuk menggunakan sumber daya perusahaan secara tidak wajar dan salah menyajikan fakta untuk memperoleh keuntungan pribadi.

Ikatan Akuntan Indonesia (2001) menjelaskan kecurangan akuntansi sebagai: (1) Salah saji yang timbul dari kecurangan dalam pelaporan keuangan yaitu salah saji atau penghilangan secara sengaja jumlah atau pengungkapan dalam laporan keuangan untuk mengelabuhi pemakai laporan keuangan, (2) Salah saji yang timbul dari perlakuan tidak semestinya terhadap aktiva (seringkali disebut dengan penyalahgunaan atau penggelapan) berkaitan dengan pencurian aktiva entitas yang berakibat laporan keuangan tidak disajikan sesuai dengan prinsip akuntansi yang berlaku umum di Indonesia. Indonesia termasuk negara yang memiliki tingkat korupsi tertinggi 
di dunia yaitu peringkat 118 dari 182 negara (transparency international, 2012), sedangkan hasil Failed State Index, (2012), Indonesia berada di urutan 100 dari 182 negara. Kondisi ini menunjukkan bahwa korupsi di Indonesia belum banyak berubah. Di Indonesia, kecurangan akuntansi dibuktikan dengan adanya likuidasi beberapa bank, diajukannya manajemen BUMN dan swasta ke pengadilan, kasus kejahatan perbankan, manipulasi pajak, korupsi di komisi penyelenggaraan pemilu, dan DPRD

Untuk dapat memecahkan permasalahan kecurangan akuntansi perlu dirancang suatu sistem pengendalian internal atau control intern yang efektif. Pengendalian internal adalah proses yang dirancang untuk memberikan kepastian yang layak mengenai pencapaian tujuan manajemen tentang reliabilitas pelaporan keuangan, efektivitas dan efisiensi operasi, dan kepatuhan terhadap hukum dan peraturan yang berlaku (Arens, 2006: 412). Seperti yang dikutip oleh Wilopo (2006: 5) menyatakan bahwa pengendalian internal yang efektif mengurangi kecenderungan kecurangan akuntansi. Jika suatu sistem pengendalian internal lemah maka akan mengakibatkan kekayaan perusahaan tidak terjamin keamananya, informasi akuntansi yang ada tidak teliti dan tidak dapat dipercaya, tidak efisien dan tidak efektifnya kegiatan-kegiatan operasional perusahaan serta tidak dapat dipatuhinya kebijaksanaan manajemen yang ditetapkan. Pengendalian internal memegang peranan penting dalam organisasi untuk meminimalisir terjadinya kecurangan. Pengendalian internal yang efektif akan menutup peluang terjadinya perilaku yang tidak etis serta kecenderungan untuk berlaku curang serta budaya etis organisasi juga akan meningkat seiring dengan peningkatan kesadaran anggota organisasi terhadap hadirnya pengawasan yang integral dan bersinambungan.

Pelanggaran etika yang berujung pada skandal akuntansi telah banyak terjadi, kasus perusahaan Enron (2010) merupakan perusahaan terbesar ke tujuh di Amerika Serikat yang bergerak di bidang industri energi yang jatuh bangkrut karena manipulasi laporan keuangan dengan mencatat keuntungan yang padahal perusahaan tersebut mengalami kerugian. Tidak hanya gagal karena praktek akuntansi tetapi juga gagal karena memiliki budaya yang mendorong eksekutif ke dalam perilaku tidak etis (Suyoso, 2012). Budaya etis organisasi adalah presepsi karyawan mengenai suatu pola tingkah laku kepercayaan yang telah menjadi suatu panutan bagi semua organisasi.Tingkah laku disini merupakan seluruh tingkah laku yang dapat diterima secara hukum (Pristiyanti, 2012). Budaya organisasi memberi kontribusi yang signifikan terhadap pembentukan perilaku etis, karena budaya organisasi merupakan seperangkat nilai dan norma yang membimbing tindakan karyawan. Budaya dapat mendorong terciptanya perilaku etis, dan sebaliknya dapat pula mendorong terciptanya perilaku yang tidak etis. Jadi dapat disimpulkan bahwa budaya etis organisasi adalah sistem nilai, norma dan kepercayaan yang bersama-sama dimiliki oleh masing-masing anggota organisasi yang kemudian mempengaruhi cara bekerja dan 
berperilaku dari para anggota organisasi agar terciptanya perilaku baik dan beretika, dan menghindari tindakantindakan yang dapat merugikan organisasi.

Budaya etis organisasi dan sistem pengendalian internal merupakan suatu kesatuan yang saling berkaitan satu dengan yang lain. Dengan adanya pengendalian internal organisasi, maka dengan sendirinya sistem yang akan melakukan pengawasan guna mencapai visi, misi dan tujuan organisasi. Namun sistem pengendalian internal juga tidak dapat berjalan dengan baik tanpa didukung dengan budaya organisasi yang baik. Dengan adanya budaya etis organisasi yang mempengaruhi setiap anggota organisasi dalam bertindak sesuai dengan etika bisnis yang berlaku maka pengendalian internal dapat berjalan tanpa hambatan yang berarti karena sistem tidak dapat berjalan tanpa campur tangan manusia didalamnya. Faktor yang paling penting dalam pengendalian internal adalah orang-orang yang dapat menunjang sistem berjalan dengan baik. Ketika sistem pengendalian internal melakukan fungsi pengawasan, dan didukung dengan pelaksanaan kegiatan organisasi yang beretika maka selanjutnya, apabila kondisi ini dipertahankan maka terciptalah intern control culture, artinya sistem pengendalian internal menjadi bagian dari budaya organisasi.

Ketaatan terhadap aturan akuntansi juga merupakan faktor yang mempengaruhi terjadinya kecenderungan kecurangan akuntansi.Wilopo (2006) mengatakan bahwa untuk mengatasi permasalahan keagenan seharusnya manajemen perusahaan melaksanakan aturan akuntansi dengan benar. Merujuk pada Agency Theory maka potensi konflik kepentingan selalu ada antara agent dan principle. Aturan akuntansi memberikan pedoman bagi manajemen bagaimana melakukan kegiatan akuntansi dengan baik dan benar sehingga menghasilkan laporan keuangan yang efektif dan mampu menghasilkan informasi yang handal kepada pihak yang berkepentingan. IAI (2002), menyatakan bahwa masyarakat membutuhkan kredibilitas informasi, untuk mendapatkan kredibilitas informasi tersebut manajemen harus melaksanakan aturan akuntansi yang berlaku umum.

Beberapa penelitian telah dilakukan sebelumnya, diantaranya adalah penelitian yang dilakukan oleh Wilopo (2006), Thoyibatun (2012), Kusumastuti (2012), Pramudita (2013) dan Artini (2014). Mengacu pada penelitian tersebut, penelitian ini akan mengkaji kembali tentang pengaruh efektivitas pengendalian internal, budaya etis organisasi dan ketaatan aturan akuntansi untuk mengatasi kecenderungan kecurangan akuntansi pada SKPD kota Ternate.

\section{KAJIAN PUSTAKA}

\section{Efektitas Pengendalian Internal dan Kecenderungan Kecurangan Akuntansi}

Tujuan dari pengendalian internal adalah agar kegiatan operasional perusahaan berjalan secara efektif dan efisien sehingga tujuan perusahaan dapat tercapai. Menurut Kusumastuti (2012) sistem pengendalian internal diharapkan mampu 
mengurangi adanya tindakan menyimpang yang dilakukan oleh manajemen. Manajemen cenderung melakukan tindakan menyimpang untuk memaksimalkan keuntungan pribadi. Salah satu contoh tindakan menyimpang yaitu kecenderungan melakukan kecurangan. Salah satu contoh pengendalian internal adalah adanya beberapa prosedur yang harus dilalui ketika akan melakukan transaksi seperti otorisasi dari pihak yang berwenang. Jika pengendalian tidak berjalan dengan baik, prosedur tidak dilakukan sebagaimana mestinya, maka akan membuka kesempatan bagi pegawai yang terlibat dalam kegiatan operasional organisasi untuk melakukan kecurangan. Penelitian Wilopo (2006) menunjukkan bahwa keefektifan pengendalian internal berpengaruh negatif terhadap kecenderungan kecurangan akuntansi. Jadi, dengan sistem pengendalian internal yang baik, akan meminimalisir kecurangan akuntansi yang dilakukan oleh pegawai. Sedangkan Zainal (2009) menemukan bahwa efektivitas pengendalian internal berpengaruh signifikan positif terhadap kecurangan akuntansi pada kantor cabang bank pemerintah dan swasta dikota Padang. Berdasarkan argumen tersebut, maka dapat dirumuskan hipotesis:

H1 : Efektifitas Pengendalian Internal berpengaruh Terhadap Kecenderungan

Kecurangan Akuntansi.

\section{Budaya Etis Organisasi dan Kecenderungan Kecurangan Akuntansi}

Budaya organisasi merupakan sistem makna bersama yang dianut oleh anggotaanggota yang membedakan organisasi itu dari organisasi yang lain. Dengan demikian budaya organisasi adalah nilai yang dirasakan bersama oleh anggota organisasi yang diwujudkan dalam bentuk sikap perilaku pada organisasi. Arifiyani dkk., (2012). Penelitian Pristiyanti (2012) menunjukkan bahwa budaya etis organisasi berpengaruh terhadap kecurangan di sektor pemerintahan. Sedangkan Artini dkk., (2014) menunjukan adanya pengaruh negatif dan signifikan antara budaya etis organisasi terhadap kecenderungan kecurangan akuntansi. Dengan demikian, semakin baik iklim budaya etis yang dapat diciptakan dalam lingkungan perusahaan akan meminimalisir kecenderungan kecurangan akuntansi (fraud) yang Dilakukan pegawai. Berdasarkan argumen tersebut, maka dapat dirumuskan hipotesis:

H2 : Budaya Etis Organisasi Berpengaruh Terhadap Kecenderungan Kecurangan Akuntansi.

\section{Ketaatan Aturan Akuntansi dan Kecenderungan Kecurangan Akuntansi}

Penyajian laporan akuntansi oleh organisasi merupakan kewajiban sehubungan dengan tugas dan tanggung jawab yang telah didelegasikan kepada pimpinan. Untuk itu maka ada dua kebutuhan yang perlu dipenuhi, yaitu kebutuhan pemakai (sebagai pihak ekstern) dan pimpinan selaku pihak pengelola aset dan penyaji laporan keuangan. Penelitian dengan penelitian Wilopo (2006) yang menemukan bahwa ketaatan aturan akuntansi berpengaruh negatif terhadap kecenderungan kecurangan 
akuntansi. Berbeda dengan penelitian Thoyibatun (2009) yang menunjukkan ketaatan aturan akuntansi berpengaruh positif terhadap kecenderungan kecurangan akuntansi. Semakin baik iklim ketaatan pada aturan akuntansi yang dapat diciptakan dalam lingkungan perusahaan akan meminimalisir kecenderungan kecurangan akuntansi (fraud) yang dilakukan pegawai. Berdasarkan argumen tersebut, maka dapat dirumuskan hipotesis:

H3 : Ketaatan Aturan Akuntansi Berpengaruh terhadap Kecenderungan Kecurangan Akuntansi.

\section{METODE PENELITIAN}

\section{Metode Pengambilan Sampel}

Populasi dari penelitian ini adalah semua pihak yang menerima delegasi wewenang dan tanggung jawab untuk terlibat dalam penggunaan dana yang dianggarkan, pelaksana akuntansi, dan orang yang bertugas berkaitan dengan laporan keuangan dan laporan pertanggung jawaban pada seluruh SKPD Kota Ternate. Sampel yang digunakan dalam penelitian ini didapat dengan teknik pengambilan sampel (teknik sampling) Nonprobability Sampling dengan Sampling jenuh. Sampling jenuh adalah teknik penentuan sampel bila semua anggota populasi digunakan sebagai sampel. Sugiyono (2013: 68). Lebih lanjut Arikunto (2006: 134) mengemukakan apabila subyeknya kurang dari 100, lebih baik diambil semua sehingga penelitiannya merupakan penelitian populasi.

\section{Jenis dan Sumber Data}

Jenis data yang digunakan dalam penelitian ini adalah data primer yaitu informasi yang diperoleh langsung dari Dinas-dinas Satuan Kerja Perangkat Daerah (SKPD) Kota Ternate melalui observasi langsung dan survei dengan cara memberikan kuesioner kepada para responden. Kuesioner yang digunakan meliputi empat bagian yaitu kuisioner untuk meneliti kecenderungan kecurangan akuntansi, efektifitas pengendalian internal, budaya etis organisasi, dan ketaatan aturan akuntansi.

\section{Definisi Operasional Variabel}

Variabel adalah suatu simbol yang diberi nilai atau angka, yang merupakan suatu konsep atau hal yang akan diteliti. Dalam penelitian yang menjadi variabel independen yaitu variabel efektifitas pengendalian internal, budaya etis organisasi dan ketaatan aturan akuntansi. Sedangkan yang menjadi variabel dependen adalah kecenderungan kecurangan akuntansi. Variabel tersebut dapat didefenisikan sebagai berikut: 
a. Kecenderungan Kecurangan Akuntansi

Kecurangan sering disebut sebagai kejahatan kerah putih (white collar crime) apabila kecurangan dilakukan oleh pihak manajemen yang dapat merusak keseluruhan organisasi atau perusahaan. Kecurangan ini umumnya berupa tindakan untuk kepentingan diri sendiri yang direkayasa oleh pihak manajemen yang dapat mengakibatkan kerugian besar bagi perusahaan sehingga kemungkinan perusahaan dapat mengalami kebangkrutan. Penelitian ini menggunakan indikator yang dikembangkan oleh Siregar (2012) yaitu kecurangan laporan keuangan, penyalahgunaan aset dan korupsi.

b. Budaya Etis Organisasi

Budaya etis organisasi adalah persepsi karyawan mengenai suatu pola tingkah laku, kepercayaan yang telah menjadi suatu panutan bagi semua anggota organisasi.Tingkah laku disini merupakan seluruh tingkah laku yang dapat diterima oleh moral dan dapat diterima secara hukum. Indikator budaya organisasi dikembangkan dengan merujuk pada penelitian Pristiyanti (2012) yaitu model peran yang visble, komunikasi harapan-harapan etis, pelatihan etis, hukuman bagi tindakan etis dan mekanisme perlindungan etika.

c. Efektifitas Pengendalian Internal Pengendalian internal merupakan "garis depan pertahanan" dalam memastikan keamanan asset (sebagai hasil pengadaan) dan mencegah serta mendeteksi adanya penyimpangan serta fraud. Pengendalian internal juga membantu manajemen organisasi publik mewujudkan hasil yang diinginkan melalui pengelolaan sumber daya publik secara efisien dan efektif merujuk pada penelitian Herawati (2007) yaitu lingkungan pengendalian, penilaian risiko, kegiatan pengendalian, informasi dan komunikasi dan pemantauan pengendalian internal

d. Ketaatan Aturan Akuntansi

Aturan merupakan tindakan atau perbuatan yang harus dijalankan. Aturan akuntansi dibuat sedemikian rupa sebagai dasar dalam penyusunan laporan keuangan. Indikator penelitian ini dikembangkan dari penelitian Rahmawati (2012) yaitu tanggung jawab penerapan, kepentingan publik, integritas, objektivitas, kehati-hatian, kerahasiaan, konsistensi dan standar teknis.

\section{HASIL PENELITIAN DAN PEMBAHASAN}

\section{Statistik Deskriptif}

Penelitian ini melibatkan sebanyak empat variabel yaitu Budaya Etis Organisasi (X1), Efektifitas Pengendalian Internal (X2), Ketaatan Aturan Akuntansi (X3) dan Kecenderungan Kecurangan Akuntansi (Y). Penentuan kategori skor berdasarkan kategori jawaban responden menggunakan 5 (lima) skala likert. dimana responden diminta untuk memilih jawaban yang paling tepat dengan 5 macam alternatif(Sangat 
Tidak Setuju $(\mathrm{STS})=1$, Tidak Setuju $(\mathrm{TS})=2, \operatorname{Netral}(\mathrm{N})=3$, Setuju $(\mathrm{S})=4$, Sangat Setuju $(\mathrm{SS})=5)$.

Tabel 1. Deskripsi Statistik

\begin{tabular}{lccccc}
\hline & N & Minimum & Maximum & Mean & $\begin{array}{c}\text { Std. } \\
\text { Deviation }\end{array}$ \\
\hline Efektifitas Pengendalian Internal & 72 & 3.00 & 5.00 & 4.2917 & .39850 \\
Budaya Etis Organisasi & 72 & 2.60 & 5.00 & 4.0444 & .60068 \\
Ketaatan Aturan Akuntansi & 72 & 1.43 & 4.43 & 3.0236 & .61537 \\
Kecenderungan Kecurangan & 72 & 1.00 & 4.33 & 2.0228 & .61745 \\
Akuntansi & 72 & & & & \\
Valid N (listwise) & & & & & \\
\hline
\end{tabular}

Sumber: Olah data SPSS

Hasil deskripsi tersebut di atas menunjukan bahwa pada efektifitas pengendalian internal, budaya etis organisasi dan ketaatan aturan akuntansi pada SKPD di kota Ternate rata-rata cukup baik dan kecenderungan kecurangan akuntansi pada SKPD di kota Ternate cukup rendah.

\section{Pengujian Hipotesis}

Pengujian hipotesis dengan analisis regresi berganda digunakan untuk menganalisis data dengan tingkat keyakinan $95 \%$ atau tingkat kesalahan yang dapat ditoleransi 5\%. Uji Hipotesis dalam penelitian ini menggunakan metode analisis regresi berganda. Dari hasil pengolahan data yang meliputi variabel-variabel efektifitas pengendalian internal, budaya etis organisasi dan ketaatan aturan akuntansi terhadap kecenderungan kecurangan akuntansi diperoleh hasil sebagai berikut:

\section{Tabel 2. Hasil Analisis Regresi Berganda}

\begin{tabular}{lcccc}
\hline Variabel & $\begin{array}{c}\text { Koefisien } \\
\text { Regresi }\end{array}$ & $\begin{array}{c}\text { Standardized } \\
\text { Coefisients } \\
\text { (Beta) }\end{array}$ & T & Sig \\
\hline (Constant) & 1,842 & & 2,213 & 0,030 \\
Efektifitas Pengendalian Internal & $-0,132$ & 0,219 & $-0,723$ & 0,047 \\
Budaya Etis Organisasi & $-0,136$ & 0,195 & $-0,981$ & 0,030 \\
Ketaatan Aturan Akuntansi & $-0,429$ & 0,190 & $-3,278$ & 0,002 \\
R =0,610R Square =0,460Std Error $=0,37823 \mathrm{~F}=4,320$ Sig F $=0,008$ & & \\
Sumber: Olah Data SPSS
\end{tabular}

Berdasarkan hasil tersebut di atas, maka model regresi linier berganda sebagai berikut:

$\mathrm{Y}=1,842-0,132 \mathrm{X} 1-0,136 \mathrm{X} 2-0,429 \mathrm{X} 3+\mathrm{e}$

Berdasarkan pada tabel diatas menunjukkan bahwa $\mathrm{F}_{\text {hitung }}$ adalah 4,320 dengan tingkat signifikansi sebesar 0,008 lebih kecil dari $\alpha=0,05$ sehingga dapat dinyatakan 
bahwa secara simultan variabel efektifitas pengendalian internal, buadaya etis organisasi dan ketaatan aturan akuntansi berpengaruh signifikan terhadap kecenderungan kecurangan akuntansi di SKPD kota Ternate. Dari hasil pengujian Goodness of fit model yang ditunjukkan dengan $R$-squared menghasilkan koefisien sebesar 0,460 yang artinya variabel independen mampu menjelaskan variasi dari variabel dependen yaitu kecenderungan kecurangan akuntansi sebesar $46 \%$ dan sisanya sebesar 54\% dapat dijelaskan oleh faktor-faktor lain yang tidak diikut sertakan dalam pengujian penelitian ini. Pengujian secara parsial yang telah dilakukan menyimpulkan bahwa variabel efektifitas pengendalian internal, budaya etis organisasi dan ketaatan aturan akuntansi berpengaruh signifikan terhadap kecenderungan kecurangan akuntansi. Hal ini dapat terlihat dari nilai signifikansi dari masing-masing variabel tersebut yang lebih kecil dari 0,05 yakni nilai signifikansi dari variabel efektifitas pengendalian internal sebesar 0,047 , variabel budaya etis organisasi dengan nilai signifikansi sebesar 0.030 dan variabel ketaatan aturan akuntansi dengan nilai signifikansi sebesar 0,072 .

\section{PEMBAHASAN}

\section{Pengaruh Efektifitas Pengendalian Internal terhadap Kecenderungan Kecurangan Akuntansi}

Dari hasil pengujian hipotesis kedua diperoleh bukti empiris bahwa bahwa efektifitas pengendaliann internal berpengaruh negatif signifikan terhadap kecenderungan kecurangan akuntansi. Dengan demikian, semakin efektif sistem pengendalian internal dalam suatu instansi, maka kemungkinan terjadinya kecurangan dalam instansi tersebut akan semakin rendah.

Teori Fraud Triangel menyatakan bahwa seseorang selalu mempunyai kesempatan (oppurtunity) untuk melakukan kecurangan. Akan tetapi, dengan memperkecil kesempatan dapat menurunkan kecurangan, kesempatan dapat ditekan melalui sistem pengendaliann internal yang efektif (Tunggal, 2014: 19). Hal ini menunjukkan bahwa semakin tinggi tingkat efektivitas pengendaliann internal maka akan mampu menurunkan kecenderungan kecurangan akuntansi.

Pengendaliann internal meliputi lima kategori yang dirancang dan diimplementasikan oleh manajemen untuk memberikan jaminan bahwa sasaran hasil Pengendaliann manajemen akan terpenuhi, komponen pengendaliann internal menurut Badan Pengawas Pasar Modal dan Lembaga Keuangan (2006) adalah:

1. Lingkungan Pengendalian terdiri dari tindakan, kebijakan, dan prosedur yang mencerminkan sikap dari manajemen puncak, para direktur, dan pemilik dari suatu entitas mengenai pengendalian internal dan penting nya komponen bagi entitas itu.

2. Penilaian Resiko adalah identifikasi manajemen dan analisis resiko yang relevan dengan persiapan laporan keuangan yang sesuai dengan prinsip berlaku umum. 
3. Aktivitas Pengendalian adalah kebijakan dan prosedur yang dibuat untuk memberikan keyakinan bahwa petunjuk yang dibuat oleh manajemen dilaksanakan.

4. Informasi dan Komunikasi, sistem informasi yang relevan dengan tujuan laporan keuangan yang meliputi sistem akuntansi.

5. Pemantauan adalah proses penilaian kualitas kinerja struktur Pengendalian intern sepanjang waktu.

Hasil penelitian ini sejalan dengan penelitian yang dilakukan oleh Rahmawaty (2012) yang menemukan bahwa efektifitas pengendalian internal berpengaruh negatif terhadap kecenderungan kecurangan akuntansi. Hasil penelitian ini juga sejalan dengan penelitian yang dilakukan Wilopo (2006) yang menemukan bahwa semakin baik dan semakin efektif suatu pengendalian internal maka akan semakin rendah tingkat terjadinya fraud di sektor pemerintahan. Hal ini mendukung pendapat Wilopo (2006) bahwa adanya suatu sistem pengendalian internal bagi sebuah organisasi sangatlah penting, antara lain untuk memberikan perlindungan bagi entitas terhadap kelemahan manusia serta untuk mengurangi kemungkinan kesalahan dan tindakan yang tidak sesuai dengan peraturan, sehingga fraud dapat ditekan dengan adanya penerapan sistem pengendalian internal yang baik dalam suatu organisasi atau pemerintahan.

Keefektifan pengendalian internal sangat diperlukan dalam kegiatan operasional untuk menjaga stabilitas dan kinerja organisasi di suatu instansi. Dengan adanya pengendalian Internal setiap kegiatan yang ada di dalam suatu instansi dapat terkontrol dengan baik sesuai dengan yang diharapkan atau direncanakan sebelumnya (Putri, 2014).

\section{Pengaruh Budaya Etis Organisasi terhadap Kecenderungan Kecurangan Akuntansi}

Dari hasil pengujian hipotesis pertama diperoleh bukti empiris bahwa budaya etis organisasi berpengaruh negatif signifikan terhadap kecenderungan kecurangan akuntansi. Dengan demikian, semakin meningkat budaya etis organisasi dalam suatu instansi, maka akan mampu menurunkan kecenderungan kecurangan akuntansi

Riyanto (2009) dalam Najahningrum (2013) menyarankan tindakan-tindakan beikut ini untuk mengembangkan iklim etika dalam organisasi, Manajer hendaknya berlaku etis, karena manajer merupakan model peran yang jelas, untuk mengembangkan perilaku etis harus dilakukan sejak awal yaitu sejak seleksi karyawan dilakukan. Penyaringan yang lebih teliti di bidang ini dapat menyaring mereka untuk tidak berbuat kesalahan dikemudian hari, mengembangkan kode etik yang lebih berarti, menyediakan pelatihan etika, peningkatkan perilaku etis dan membentuk posisi, unit, dan mekanisme struktural lain yang menggunakan etika. Etika harus 
menjadi kegiatan sehari-hari, bukan kegiatan yang sekali dilakukan kemudian disimpan dan dilupakan.

Hasil penelitian ini sesuai dengan penelitian Artini dkk.,(2014) yang menemukan bahwa budaya etis organisasi berpengaruh negatif signifikan terhadap kecenderungan kecurangan akuntansi. Dengan diterapkanya suatu budaya etis dalam organisasi maka akan dapat mendorong seseorang untuk dapat melakukan tindakantindakan yang beretika sehingga kecenderungan kecurangan akuntansi dapat dihindarkan.

\section{Pengaruh Ketaatan Aturan Akuntansi Terhadap Kecenderungan Kecurangan Akuntansi}

Hasil penelitian ini menunjukkan bahwa ketaatan aturan akuntansi berpengaruh negatif signifikan terhadap kecenderungan kecurangan akuntansi. Dengan didukungnya hipotesis ketiga pada penelitian ini, maka menyediakan bukti empiris bahwa semakin tinggi ketaatan pada aturan akuntansi pada pemerintahan maka semakin rendah kecenderungan kecurangan pemerintahan untuk melakukan kecurangan akuntansi. Hasil penelitian ini juga konsisten dengan teori yang dinyatakan Jensen and Meckling (1976) dalam Adelin dan Fauzihardania (2013) teori keagenan yang menyatakan bahwa taat terhadap aturan akuntansi dapat memperkecil perilaku curang, serta teori yang dinyatakan Wolk and Tearney (1997:93-95) dalam Wilopo menjelaskan bahwa kegagalan penyusunan laporan keuangan yang disebabkan karena ketidak ketaatan pada aturan akuntansi, akan menimbulkan kecurangan pemerintahan yang tidak dapat dideteksi oleh para auditor.

Hasil penelitian ini juga konsisten dengan penelitian yang dilakukan oleh Wilopo (2006), yang meneliti analisis faktor-faktor yang mempengaruhi kecenderungan kecurangan akuntansi pada BUMN dan perusahan terbuka di Indonesia. Hasil riset tersebut menunjukkan bahwa ketaatan aturan akuntansi berpengaruh signifikan dan negatif terhadap kecenderungan kecurangan akuntansi.

\section{SIMPULAN}

Efektifitas pengendalian internal berpengaruh negatif signifikan terhadap kecenderungan kecurangan akuntansi pada SKPD kota Ternate. Budaya etis organisasi berpengaruh negatif signifikan terhadap kecenderungan kecurangan akuntansi pada SKPD Kota Ternate. Ketaatan aturan akuntansi berpengaruh negatif signifikan terhadap kecenderungan kecurangan akuntansi pada SKPD Kota Ternate.

Keterbatasan dalam peneltian ini adalah: Dimana dari model penelitian yang digunakan, diketahui bahwa variabel penelitian yang digunakan hanya dapat menjelaskan sebesar $46 \%$ sedangkan 54\% dijelaskan oleh faktor lain yang tidak diteliti. Sehingga variabel penelitian yang digunakan terbatas dalam menjelaskan pengaruhnya terhadap kecenderungan kecurangan akuntansi. Penelitian ini merupakan 
metode survei menggunakan kuesioner tanpa dilengkapi dengan wawancara atau pertanyaan lisan sehingga peneliti tidak bisa mengontrol jawaban responden apabila responden tidak jujur dalam menjawab pertanyaan yang diajukan. Responden tidak didampingi saat pengisian kuesioner sehingga dikhawatirkan terjadi kesalahan persepsi dari responden saat menjawab pertanyaan.

\section{DAFTAR PUSTAKA}

Adelin, V., dan Fauzihardani, Eka. 2013. Pengaruh Pengendalian Internal, Ketaaatan Pada Aturan Akuntansi Dan Kecenderungan Kecurangan Terhadap Perilaku Tidak Etis.WRA,Vol. 1, No. 2.

Aisah, S. 2010. Pengaruh Pengendalian Internal, Kepatuhan, dan Integritas Manajemen terhadap Perilaku Etis Karyawan dalam Sistem Penggajian. Skripsi: Universitas Pembangunan Nasional Veteran.

Arifiyani, H.A., dan Sukirno, D.Ph. 2012. Pengaruh Pengendalian Internal, Kepatuhan Dan Kompensasi Manajemen Terhadap Perilaku Etis Karyawan (Studi Kasus PT. Adi Satria Abadi Yogyakarta). Jurnal Nominal/Volume I Nomor I/Tahun 2012.

Arikonto, S. 2006. Prosedur Penelitian Suatu Pendekatan Praktik. Jakarta: Rineka Cipta.

Artini, Eka Ari, Adiputra, Made Pradana, dan Herawati, Nyoman Trisna. 2014. Pengaruh Budaya Etis Organisasi Dan Efektivitas Pengendalian Internal Terhadap Kecenderungan Kecurangan Akuntansi Pada Satuan Kerja Perangkat Daerah (SKPD) Kabupaten Jembrana. E-journal S1 Ak Universitas Pendidikan Ganesha. Volume 2 No.1.

Bungin, Burhan. 2008. Metodologi Penelitian Kuantitatif: Komunikasi Ekonomi, Dan Kebijakan Publik Serta Ilmu-Ilmu Lainnya. Jakarta: Kencana.

Departemen Keuangan Republik Indonesia Badan Pengawas Pasar Modal Dan Lembaga Keuangan. 2006. Penerapan Pengendalian Interen Pada Emiten Dan Perusahaan Publik.

Ghozali, I. 2009. Ekonometrika: Teori Konsep dan Aplikasi dengan SPSS 17. Badan Penerbit Universitas Diponegoro, Semarang.

Herwati, S.F. 2007. Kajian tentang pengendalian intern proses pengadaan barang/Jasa pemerintah secara elektronik (E-Procurement). UPVP. Jatim

Hermiyetti. 2008. Pengaruh Penerapan Pengendalian Internal terhadap Pencegahan Fraud Pengadaan Barang. STEKPI. Skripsi. Jakarta.

Mardiasmo. 2006. Perpajakan, Edisi Revisi, Yogyakarta: Andi.

Najahningrum, A.F. 2013. Faktor-Faktor Yang Mempengaruhi Kecenderungan Kecurangan (Fraud) Presepsi Pegawai Dinas Daerah Istimewa Yogyakarta. Skripsi. Semarang.

Pristiyanti, I.R. 2012. Persepsi Pegawai Instansi Pemerintah Mengenai Faktor-Faktor yang Mempengaruhi Fraud di Sektor Pemerintahan. Skripsi. Fakultas Ekonomi UNNES, Semarang.

Rahmawati, A.P. 2012. Analisis Faktor Internal dan Moralitas Manajemen terhadap Kecenderungan Kecurangan Akuntansi. Skripsi: Universitas Diponegoro.

Siregar, S.V. 2012. Audit Manajemen. Edisi 1. Universitas Terbuka, Tangerang Selatan.

Sugiyono. 2013. Metode Penelitian Kuantitatif Kualitatif dan R\&D.Cetakan ke-18. Bandung: CV Alfabeta.

El-Muhasaba, Vol. 7, No 1, Januari 2016 
Thoyibatun, S. 2009. Faktor-Faktor yang Berpengaruh Terhadap Perilaku Tidak Etis dan Kecenderungan Kecurangan Akuntansi. Jurnal Ekonomi dan Keuangan.

Transparency International.www.transparance.org. diakses pada Januari 2015.

Tunggal, A.W. 2014. Mendeteksi Kecurangan Dalam Akuntansi. Jakarta: Harvarindo.

Willopo. 2006. Analisis Faktor-Faktor Yang Berpengaruh Terhadap Kecenderungan Kecurangan Akuntansi Studi Pada Perusahaan Publik dan Perusahaan Badan Usaha Milik Negara. SNA IX, Padang.

Zainal, R. 2013. Pengaruh Efektivitas Pengendalian Intern, Asimetri Informasi dan Kesesuaian Kompensasi Terhadap Kecenderungan KecuranganAkuntansi (Fraud). Skripsi, Padang.

Zulkarnain, R.M. 2013. Analisis Faktor yang Mempengaruhi Terjadinya Fraud pada Dinas Kota Surakarta. Accounting Analysys Journal AAJ1 (3) (2013). 